\title{
TEKNIK SERANGAN PADA APLIKASI BERBASIS RUBY ON RAILS
}

\author{
Suryo Bramasto ${ }^{1}$, Melani Indriasari ${ }^{2}$ \\ ${ }^{1,2}$ Program Studi Informatika, Institut Teknologi Indonesia, \\ Jl. Raya Puspiptek Serpong, Tangerang Selatan - Banten, 15320, Indonesia \\ E-mail: ${ }^{1}$ suryo.bramasto@iti.ac.id, ${ }^{2}$ melcherish@gmail.com
}

\begin{abstract}
Abstrak
Ruby on Rails (Rails) merupakan salah satu framework platform aplikasi berbasis web yang dewasa ini banyak digunakan. Segala sesuatu yang berbasis web senantiasa rentan terhadap serangan cyber. Penyerang senantiasa berusaha mencari titik lemah (vulnerabilities) pada setiap framework platform berbasis web yang ada. Secara umum Rails merupakan framework yang relatif aman dari serangan, namun tetap memiliki titik lemah. Titik lemah pada sistem berbasis web pada umumnya merupakan teknik serangan, begitu pula pada Rails. Artikel ini memaparkan bagaimana membangun teknik serangan pada Rails. Teknik serangan dibangun dengan melakukan exploit yang memanfaatkan kelengahan pengembang yang tidak menerapkan cara memprogram yang aman pada Rails. Teknik serangan yang dibangun adalah menyalahgunakan fitur konversi otomatis pada tipe data dan melakukan injeksi kode.
\end{abstract}

Kata kunci- exploit, Ruby on Rails, teknik serangan, titik lemah

\begin{abstract}
Ruby on Rails (Rails) is one of the popular web applications framework nowadays. Anything web based is always prone to cyber attacks. Attackers always search for any web applications framework vulnerabilities. Rails is considered relatively save framework in term of cyber attacks, but still has vulnerabilities. Vulnerabilites on web based systems usually in the form of attack techniques, so does on Rails. This article explains about Rails attack techniques formulation. Attack techniques formulated by conducting exploit which utilizing developer inadvertence not implementing secure programming. Formulated attack techniques are abusing data type automatic conversion and by code injection.
\end{abstract}

Keywords- attack techniques, exploit, Ruby on Rails, vulnerabilities

\section{PENDAHULUAN}

Pada era informasi dewasa ini, transformasi aplikasi piranti lunak desktop ke aplikasi ekivalen berbasis web telah menjadi tren yang penting, yang mana dengan hal ini pengguna dimungkinkan untuk saling berinteraksi dan berbagi informasi melalui web browser [1]. Dengan demikian aplikasi-aplikasi berbasis web yang ada saat ini memiliki berbagai macam fungsionalitas yang dibutuhkan oleh pengguna seperti webmail, online organizer, e-business, ebanking, dan sebagainya [1]. Paradigma transformasi ke era berbasis web walau mengubah metodologi dan proses rancang bangun aplikasi secara signifikan, namun masih tetap membawa kesalahan-kesalahan perancangan yang biasa terjadi saat rancang bangun aplikasi desktop [1]. Penelitian yang telah dilakukan oleh IBM pada tahun 2012 menyatakan bahwa secara statistik pada aplikasi-aplikasi berbasis web masih banyak terdapat kerentanan (vulnerabilities), yang mana kerentanan-kerentanan ini selalu menjadi sasaran penyerang cyber [1]. Konsekuensi 
serangan pada aplikasi-aplikasi berbasis web sama kritisnya dengan pada aplikasi desktop, namun pada aplikasi berbasis web terdapat kelemahan lain dibanding aplikasi berbasis desktop yakni kerentanan yang dapat dieksploitasi dari jarak jauh (remote). Beberapa mekanisme telah dikembangkan guna melindungi aplikasi-aplikasi berbasis web dari potensi-potensi serangan. Mekanisme-mekanisme tersebut dapat diimplementasikan pada level jaringan (misalnya firewall) dan pada level aplikasi (misal teknik sanitasi masukan). Walau demikian, secara statitistik mekanisme-mekanisme tersebut banyak terbukti kurang efisien karena semantic dari aplikasi yang mana seharusnya terlindungi pada umumnya kurang menjadi perhatian. Dengan kata lain, mekanisme proteksi untuk aplikasi-aplikasi berbasis web pada umumnya belum dapat secara efisien mendeteksi serangan yang mempengaruhi integritas keadaan aplikasi.

Salah satu framework guna rancang bangun aplikasi berbasis web yang banyak digunakan adalah Ruby on Rails (Rails), yang mana banyak digunakan oleh platform terkenal antara lain Twitter (sebelum pindah ke Scala pada 2009), Airbnb, Ask.fm, Bloomberg, GitHub, Scribd, Groupon, Jobster, Kickstarter, LivingSocial, dan sebagainya [2]. Beberapa platform yang dibangun dengan Rails sebagai konsekuensi dari tujuannya membutuhkan pemenuhan terhadap prinsip keamanan informasi. Rails pada dasarnya merupakan model-view-controller (MVC) framework dengan fungsionalitas yang sangat banyak. Pada fungsionalitas dari Rails tersebutlah terdapat bug-bug, yang mana beberapa dari bug tersebut merupakan kerentanan dari sisi keamanan informasi (security vulnerabilities) [3]. Penelitian ini melakukan eksploitasi pada Rails untuk kemudian merumuskan pola dan jalur serangan pada Rails.

\section{METODE PENELITIAN}

\subsection{Identifikasi Celah Kesalahan Pemrograman dengan Rails}

\subsubsection{Sessions}

By default, Rails menyimpan client-side session di dalam cookie. Keseluruhan associative array terserialisasi (juga terenkripsi semenjak Rails 4) serta terproteksi dengan keyed-hash message authentication code (HMAC) semenjak Rails 3 agar supaya tamper-resistant. Semenjak Rails 4.1, format serialisasi yang digunakan ialah JSON encoding.

Pada dasarnya marshal merupakan format serialisasi type-length-value (TLV) yang dapat melakukan encode terhadap hampir semua object ruby. Secret key ke HMAC dan enkripsi yang diterapkan dimungkinkan tersimpan di berbagai lokasi, tergantung dari versi Rails. Kemungkinan tempat penyimpanan secret key tersebut antara lain:

- config/environment.rb

- $\quad$ config/initializers/secret_token.rb

- $\quad$ config/secrets.yml

- $\quad /$ proc/self/environ

- tempat lain yang memungkinkan guna penyimpanan cookie secret

Yang harus diperhatikan adalah, session tampering senantiasa dimungkinkan semenjak keseluruhan session data dapat terenkripsi atau tertandatangani digital. Pada umumnya user_id dari user yang sedang $\log$ in terserialisasi ke dalam session, sehingga serialisasi user_id dari tiap user lain dapar dilakukan ke dalam cookie menggunakan script sebagai berikut:

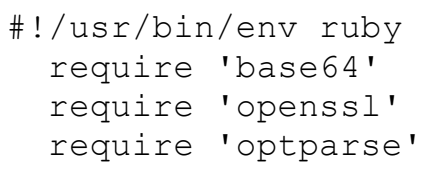


Computatio: Journal of Computer Science and Information Systems, volume 1, no 2, Oktober 2017

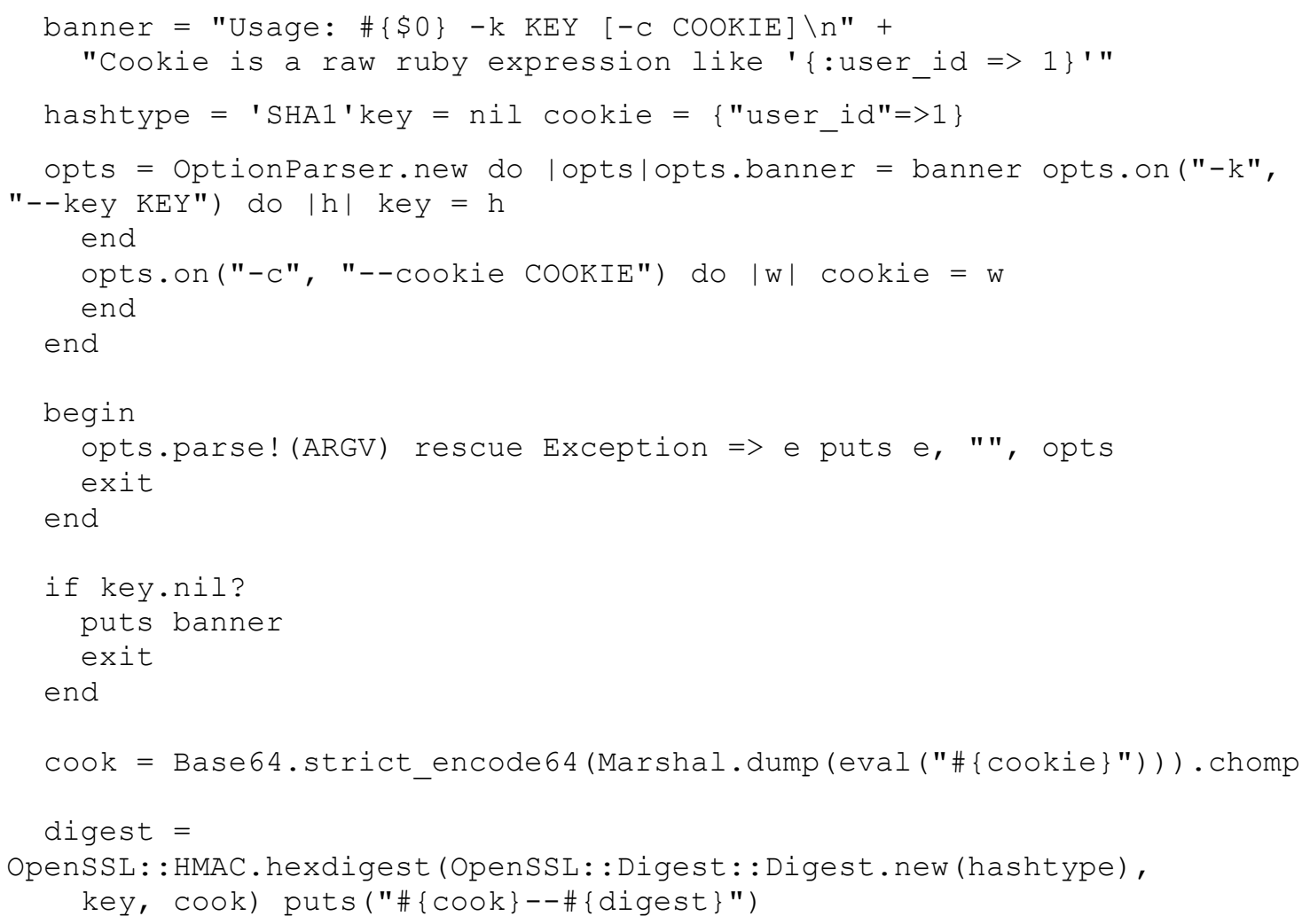

Token rahasia tidak hanya berguna untuk session tampering, melainkan bahkan dapat digunakan untuk eksekusi perintah dari jarak jauh (remote). Berikut adalah ruby method yang menghasilkan sebuah code-executing session cookie:

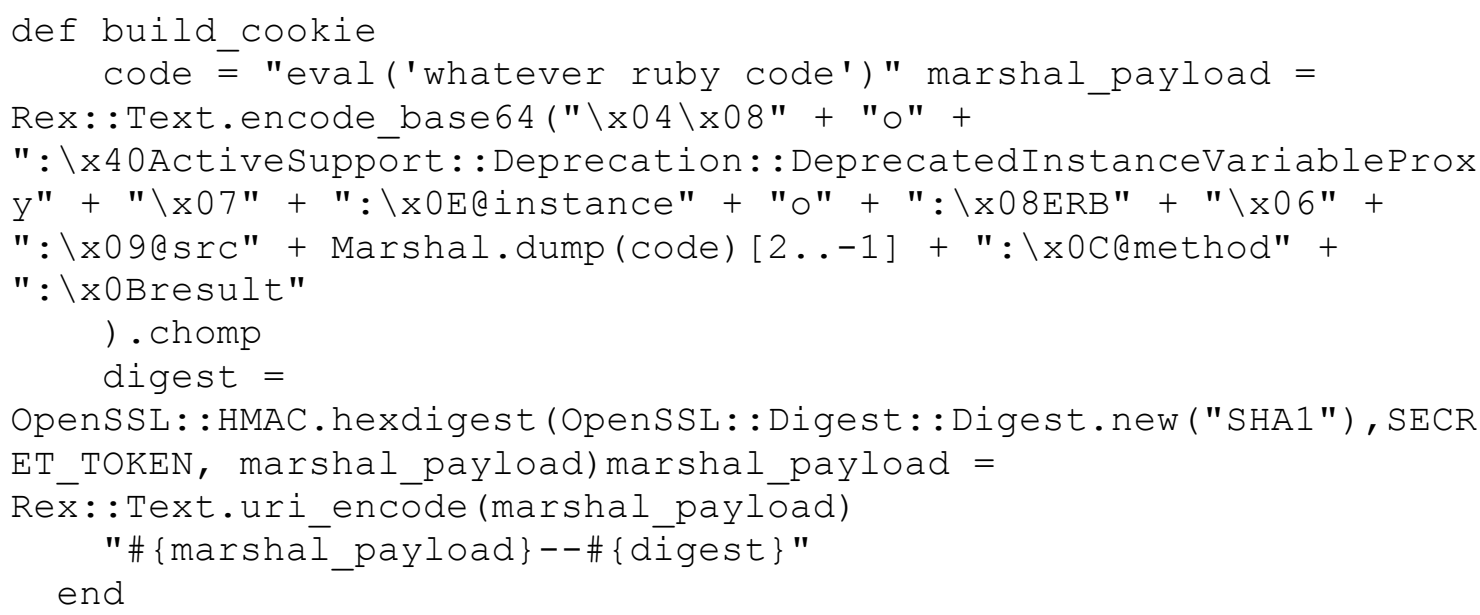

Ruby method tersebut menserialisasikan sebuah object dalam format marshal dari Ruby, dan kemudian melindungi object tersebut dengan HMAC.

Semenjak Rails 4.1, digunakan JSON encoding guna serialisasi session dengan backward compatibility untuk legacy session cookies. Legacy cookies tersebut turut disertakan pada pendefinisian token rahasia dengan basis kunci rahasia yang baru. Atau dapat juga terdapat sebuah token rahasia tanpa basis kunci rahasia, yang mana hal ini terjadi saat upgrade aplikasi berbasis Rails 3.x ke Rails 4.1 dan seterusnya. Terdapatnya legacy cookies dapat diketahui jika 
nilai cookie diawali dengan "BAh" yang mana merupakan Base64 decodes terhadap Marshal header.

Walau rahasia session tidak diketahui, namun masih terdapat celah keamanan. Misal sebuah aplikasi XYZ memiliki sebuah Rails Webinterface dan menyimpan identitas pengguna yang sedang log in di dalam session. Aplikasi XYZ akan bermasalah jika rahasia session sama untuk semua sub sistem XYZ. Misalkan aplikasi XYZ memiliki sub sistem A dan B. Jika administrator sub sistem A memiliki sebuah session cookie untuk user id 1 pada sub sistem A, maka session cookie tersebut juga sah untuk sub sistem B jika administrator sub sistem B juga memiliki session cooke untuk user id 1 . Hal tersebut dikarenakan segala sesuatu yang telah terHMAC tidak dapat dikembalikan seperti semula.

\subsection{2 to json/to $x m l$}

Proses scafolding pada Rails secara otomatis menghasilkan XML dan JSON renderers yang mencakup semua atribut dari model. Contoh permintaan terotentikasi yang merupakan perilaku Rails yang menghasilkan keluaran JSON adalah sebagai berikut [4]:

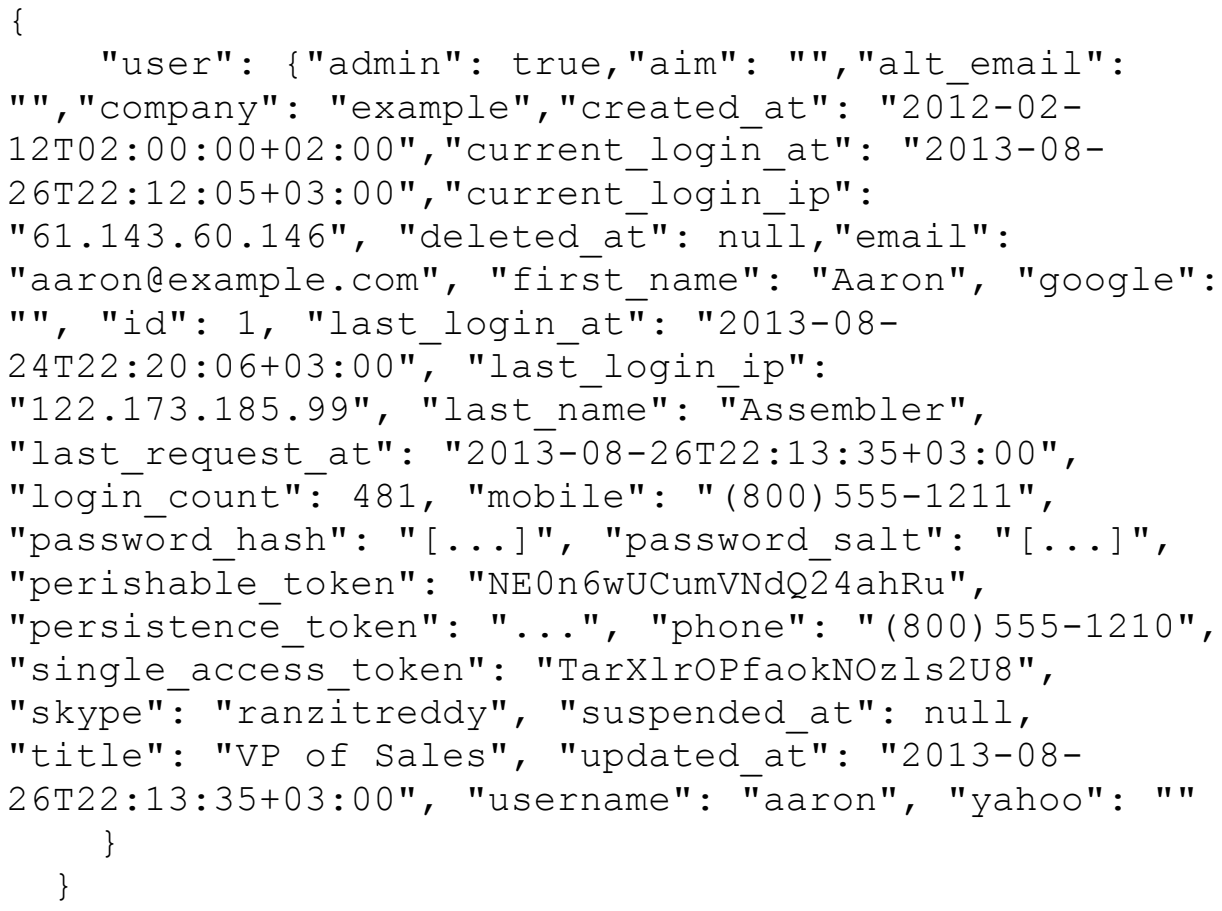

Format dari parameter dapat berupa sebuah appended .json/.xml atau sebuah format query "format=json"/"format=xml" di dalam URL. Format parameter yang mengakibatkan kerentanan yakni "format=js", walau jarang digunakan. Disebut mengakibatkan kerentanan sebagai contoh pada sebuah inbox dari pengguna sebagai berikut:

$$
\text { http://some.host/inbox/messages }
$$

Saat Javascript renderer mengeluarkan fragmen-fragmen JQuery seperti:

$$
\text { \$("\#messages"). hmtl ("here goes the user's inbox") }
$$

yang dimungkinkan mencakup: 
pada website pihak ke tiga sehingga membocorkan inbox pengguna.

\subsubsection{Kode/Eksekusi Perintah}

\subsubsection{Perintah Injeksi OS}

Pola injeksi perintah dapat diaplikasikan pada aplikasi Ruby on Rails, antara lain dengan perintah:

- 'command'

- $\quad \frac{x}{0} / \mathrm{command}$

- IO.popen (command)

- Kernel.exec

- Kernel.system

- Kernel.open ("| command")

Sedikit catatan, pada Kernel.open():, saat karakter pertama pada argumen dari Kernel.open adalah sebuah pipe, maka semua string yang muncul setelah pipe akan dianggap sebagai command line.

\subsubsection{2 eval(masukan_user)}

Method-method berikut dapat mengevaluasi muatan dari runtime/environment aplikasiaplikasi Ruby on Rails:

- $\quad$ eval (di dalam konteks aktual)

- $\quad$ instance_eval (di dalam konteks dari sebuah instance dari sebuah kelas)

- $\quad$ class_eval (di dalam konteks dari sebuah kelas)

Dimana penyerang juga dapat mengimplementasikan method-method tersebut pada masukan sehingga dimungkinkan untuk mengakses segala sesuatu dalam aplikasi.

\subsubsection{Indirections}

Hal lain yang harus diperhatikan terkait patching dan pemrograman dinamis adalah indirections dengan memanggil method-method berikut pada masukan pengguna:

- $\quad$ send

- $\quad$ send_

- public_send

- try

Yang dilakukan oleh method send yakni memanggil method terdenotasi oleh parameter pertama yang dapat berupa string atau simbol, kemudian melakukan passing argumen-argumen selanjutnya ke method yang dipanggil. Sebagai contoh diberikan suatu konstruktor sebagai berikut [5]:

$$
\text { send (params }[: a], \text { params }[: b])
$$

yang dapat diubah menjadi Remote Code Execution (RCE) dengan bentuk masukan sebagai berikut:

$$
\mathrm{a}=\mathrm{eval} \& \mathrm{~b}=\text { whatever } \% 20 \mathrm{ruby} \div 20 \mathrm{code} \div 20 \mathrm{we} \div 201 \mathrm{ike}
$$

Beberapa hal yang harus diperhatikan pada method-method indirections antara lain:

- tidak ada perbedaan antara send dan _send_

- try terdefinisi internal pada Rails sehingga mengabaikan semua exceptions

- public_send hanya memanggil method-method public pada sebuah object, namun batasan tersebut dapat dihindari dengan self-delivery seperti: 


\section{Thing.send (:hard_coded_method_name, params [someparam] )}

dimana method yang dipanggil harus hard coded sehingga kode tidak dapat secara bebas dieksekusi.

\subsubsection{Penugasan Massal}

Penugasan massal merupakan target exploit populer pada Rails, dimana konsep penugasan massal adalah aplikasi menetapkan nilai pada model secara bebas, saat model disimpan. Sebagai contoh adalah sebagai berikut:

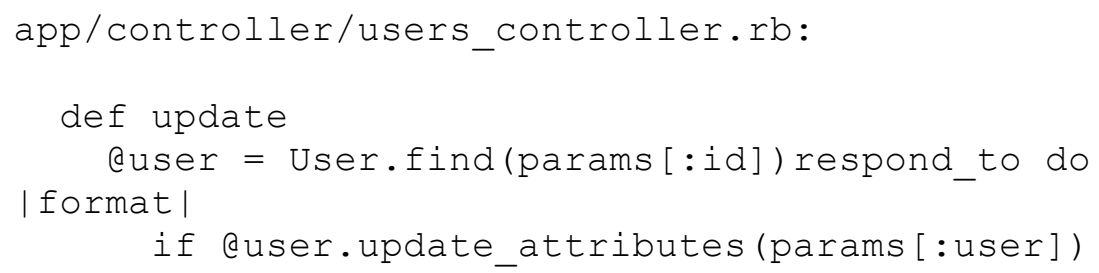

Jika model dari pengguna memiliki atribut "admin", maka setiap pengguna dapat memiliki role access sebagai admin dengan posting atribut tersebut pada aplikasi.

Kesalahan umum dalam mencegah penugasan massal ditunjukkan pada kode berikut:

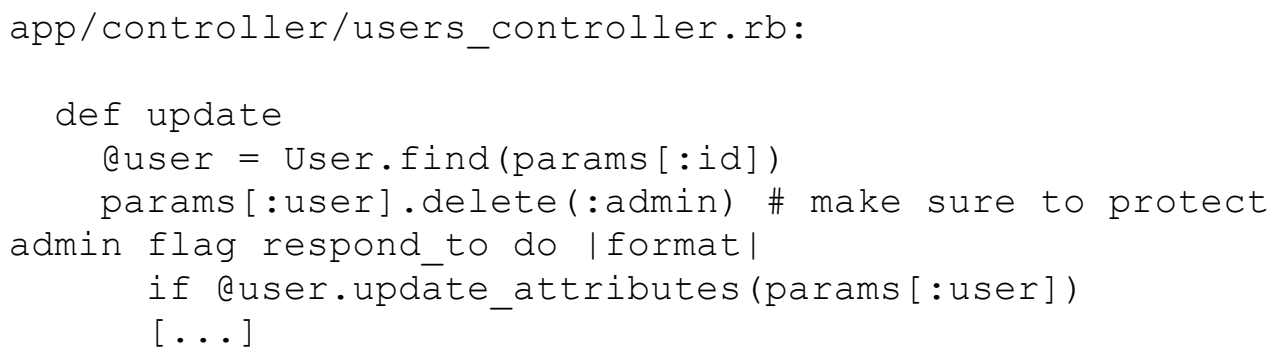

dimana dengan menggunakan controller tersebut sekaligus dengan penggunaan atribut-atribut multiparameter maka akan dapat menghindari sanitasi dengan params[:user].delete(:admin), dengan memasukkan payload user[admin(1)]=true. Atribut multiparameter akan terparsing dalam user.update_attributes, sehingga proteksi dengan params [:user].delete (:admin) tidak akan dapat menangkap atribut [admin(1)] dari pengguna, yang mana memungkinkan pengguna untuk meningkatkan privilege menjadi level administrator. Hal tersebut dimungkinkan karena parameter di dalam controller adalah "admin1", yakni berlawanan dengan "admin". Penugasan aktual dari admin1 ke admin flag terjadi pada update_attributes call.

Cara yang benar untuk mencegah atribut-atribut ditugaskan secara otomatis pada Rails adalah menggunakan attr_accessible guna mendefinisikan atribut mana yang masuk daftar putih (whitelisted) untuk penugasan massal.

\subsubsection{Ekspresi Regular}

Ruby memiliki mekanisme penanganan khusus terhadap ekspresi regular. Pencocokan dilakukan oleh regexps pada mode multi-line by default. Hal ini tidak terdapat pada bahasa pemrograman lain. Contoh penanganan ekspresi regular ditunjukkan pada perbandingan dua perintah pada command line yang ditunjukkan pada gambar 1 . 
\$ruby -e 'a="foo\nbar"; if a = /^foo\$/; puts "match"; else puts "no match"; end' match

\section{\$ perl -e '\$a="foo\nbar"; \$a = /^foo\$/ ? print "match" : ।} print "no match"'

no match

Gambar 1. Perintah-Perintah dengan Ekspresi Regular

String "foo \nbar" tidak cocok dengan ekespresi regular $/ \wedge$ foo $\$ /$ pada Perl code snippet, namun cocok pada Ruby code snippet. Inilah yang menjadi masalah utama pada penanganan ekspresi regular, yakni banyak pengembang yang tidak tahu tentang perbedaan-perbedaan tersebut. Walau demikian, hal tersebut mengakibatkan pemeriksaan dan validasi yang kurang layak. Sebagai contoh ditunjukkan pada kode controller berikut dengan ekspresi regular yang disederhanakan:

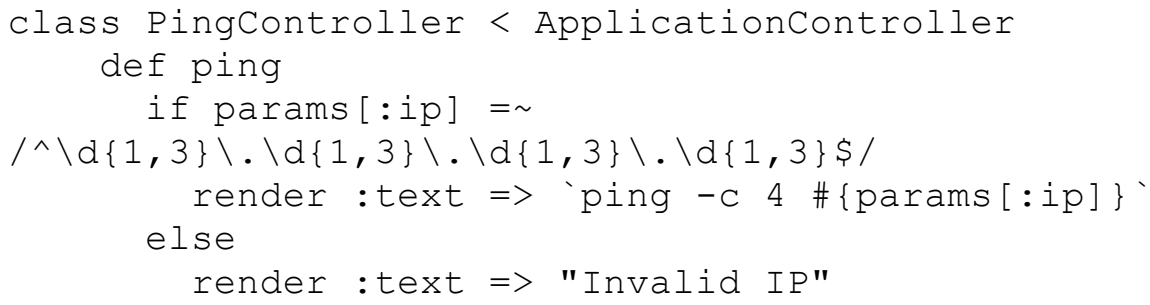

Yang diharapkan programmer terhadap kode controller tersebut adalah pencocokan antara angka dan titik di dalam validasi alamat IP. Namun dikarenakan parser ekspresi regular dari Ruby by default adalah multi line mode, maka penyerang dapat mengelak dari validasi parser dengan string seperti "1.2.3.4. In_dan_seterusnya". Simbol \$ pada ekspresi regular dari kode controller tersebut akan berhenti pada $\backslash n$, sehingga dapat dilakukan injeksi pada kode controller tersebut dengan request sederhana seperti:

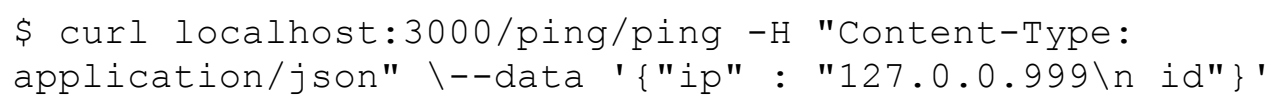

Contoh penggunaan lain dari perilaku ekspresi regular adalah verfikasi link yang diberikan pengguna. Sebagai contoh ekspresi regular $/{ }^{\wedge} \mathrm{https}$ ?:W/ dapat dilewati dengan memberikan link dengan bentuk:

$$
\text { "javascript:alert('lol')/*\nhttp://*/" (dan seterusnya) }
$$

Dimana saat input diberikan (rendered) ke atribut href dari sebuah anchor tag, maka akan membentuk Cross-Site Scripting.

\subsubsection{Renderers}

Pernyataan render pada Rails digunakan untuk memberikan (render) berbagai macam template atau plain text ke browser dari pengguna seperti render text: "Hello World!" atau dapat juga render params $[: t]$. Dengan renderer ini dimungkinkan untuk dimasukkan konten embedded ruby (ERb) dengan memberikan parameter $t$ dari: 


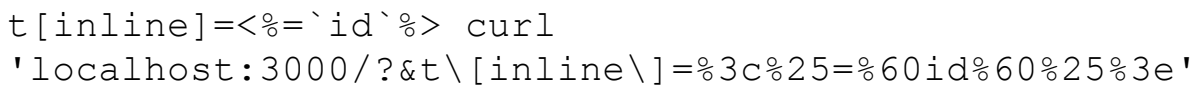

Hal ini dimungkinkan karena pernyataan render menggunakan hash sebagai argumen (yakni $t[i n l i n e]=<\frac{\circ}{0}={ }^{\prime} i{ }^{\prime} \%>$ ), dimana inline renderer mengidentifikasi sebagai ERb string sehingga kode dari pengguna akan langsung tereksekusi.

\subsubsection{Routing}

File konfigurasi config/routes.rb menjelaskan controller mana yang terjangkau dari jalur tertentu dengan verba HTTP, sehingga misalkan post "user/add" atau "users\#add_user" akan menampakkan method add_user dari UsersController pada jalur ' /users/add' melalui permintaan Post. Namun kesalahan yang banyak dilakukan pengembang adalah membuka semua jalur, misal dengan pernyataan:

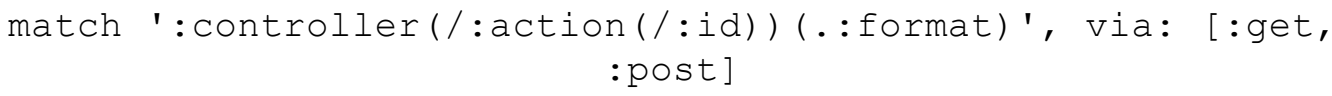

yang memaparkan semua public method dari setiap controller sehingga dapat diakses melalui permintaan-permintaan GET dan POST. Kemudian masalah utama lain adalah yakni pernyataan yang membuka semua jalur, tidak terproteksi (white-listed) pada proteksi CSRF (Cross-Site Request Forgery), dan permintaan GET juga dianggap sebagai sesuatu yang tidak mengubah keadaan (not state-changing). Sehingga apabila pengembang menggunakan pernyataan yang membuka semua jalur seperti yang telah tersebut sebelumnya, maka dengan menggunakan dua jalur penyerang dapat melakukan CSRF seperti:

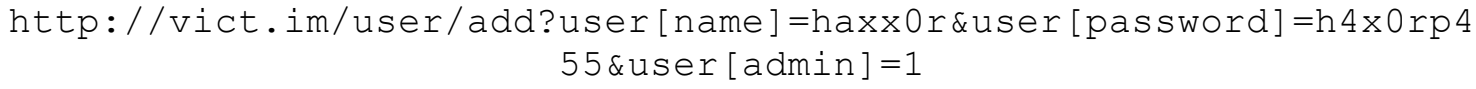

yang melanggar proteksi CSRF yang seharusnya ada pada pernyataan POST pada jalur.

\subsection{Konfigurasi Pengujian}

Dibangun suatu sistem sederhana berbasis Ruby on Rails, yang dikembangkan dengan Rails 3.1 dan Bootstrap3, seperti ditunjukkan pada gambar 1.

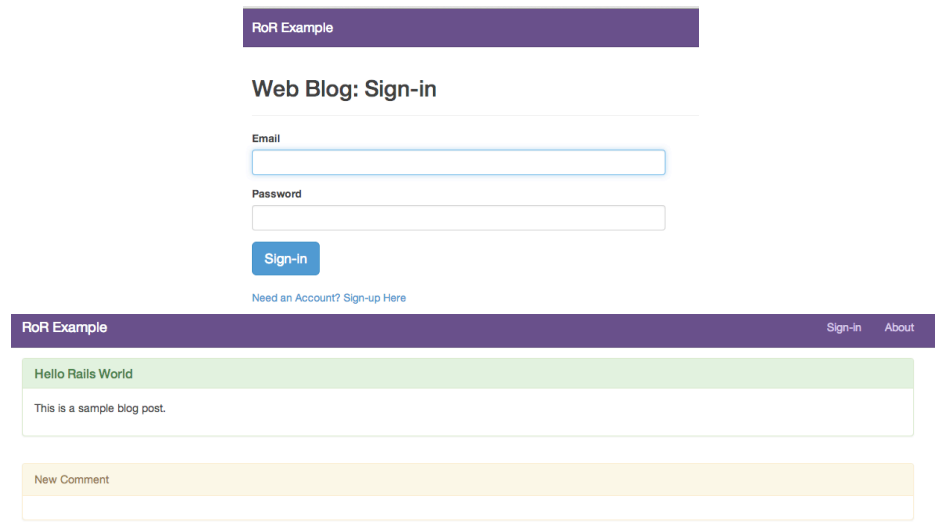

Gambar 1. Aplikasi Rails Sederhana

Kemudian digunakan juga tool-tool yakni NetworkMiner dan Brakeman guna penetration testing sebelum mengimplementasikan pola serangan yang telah dirumuskan 


\section{HASIL DAN PEMBAHASAN}

\subsection{Rails Penetration Testing}

Penetration testing pada Rails diawali dengan fingerprinting menggunakan NetworkMiner pada aplikasi Rails sederhana yang telah dikembangkan, dengan memberikan hasil seperti yang ditunjukkan pada gambar 2 dan 3.

\begin{tabular}{|c|c|}
\hline Response Header Name & Response Header Value \\
\hline Status & OK -200 \\
\hline Content-Type & text $/ \mathrm{html} ;$ charset $=\mathrm{utf}-8$ \\
\hline X-UA-Compatible & $\mathrm{IE}=\mathrm{Edge}$ \\
\hline Etag & "a89879d47f7a85b8896d9ac1fb404627" \\
\hline Cache-Control & $\max$-age $=0$, private, must-revalidate \\
\hline X-Request-Id & $93 \mathrm{~b} 54037 \mathrm{c} 12521 \mathrm{bfb} 42 \mathrm{bebfe} 7 \mathrm{f} 8110 \mathrm{e} 9$ \\
\hline X-Runtime & 0.248380 \\
\hline Server & WEBrick/1.3.1 (Ruby/1.9.3/2012-10-12) \\
\hline Date & Fri, 07 Mar 2014 12:29:35 CMT \\
\hline Content-Length & 2531 \\
\hline Connection & Keep-Alive \\
\hline Set-Cookie & _session_id $=5261 \mathrm{f0b} 796782 \mathrm{~b} 7 \mathrm{de} 8 \mathrm{ab} 06 \mathrm{f} 454 \mathrm{c} 321 \mathrm{f} 2 ;$ path $=/ ; \mathrm{HttpOnly}$ \\
\hline
\end{tabular}

Gambar 2. Fingerprinting 1

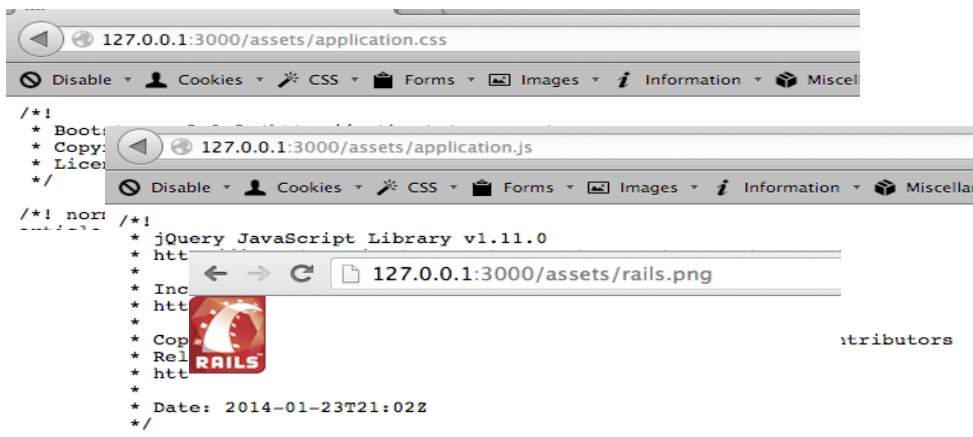

Gambar 3. Fingerprinting 2

Gambar 2 menunjukkan bahwa terdapat reverse proxy yang melayani aplikasi Rails (WEBrick), sehingga diperlukan mekanisme khusus guna code injection. Sedangkan gambar 3 ditemukan dapat dilakukan leveraging terhadap assets pipeline, yang mana merupakan kerentanan pada Rails mulai versi 3.1. Setelah dilakukan fingerprinting, diterapkan pengujian otomatis guna menemukan kerentanan menggunakan tool Brakeman. Hasil dari pengujian otomatis tersebut ditunjukkan pada gambar 4.

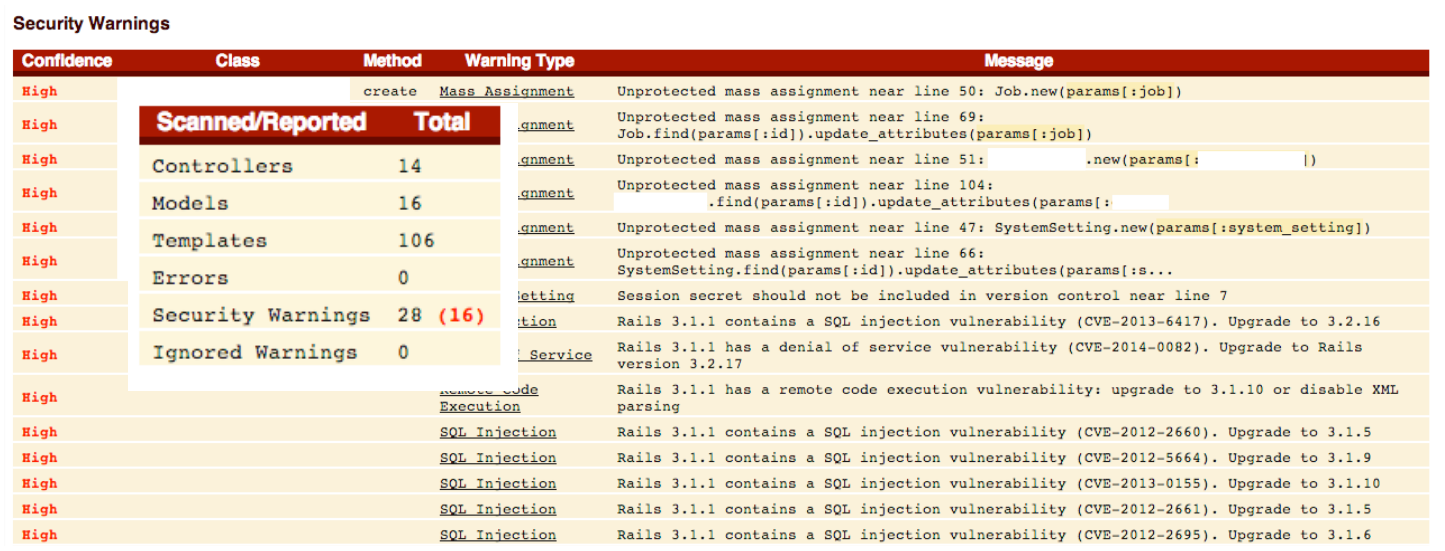

Gambar 4. Hasil Pengujian Brakeman 


\subsection{Jalur Serangan}

Hasil dari fingerprinting dan Brakeman digunakan untuk merumuskan pola serangan. Pola serangan yang dirumuskan ditunjukkan dengan alur pada gambar 5 .

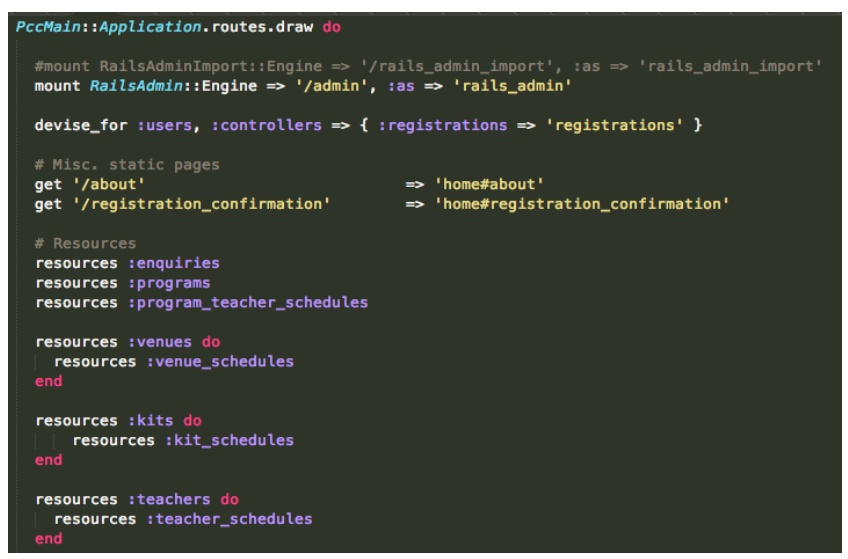

Gambar 5. Alur Serangan

Pola serangan yang dirumuskan mengarah pada serangan terhadap Session Management dengan diketahuinya dimungkinkannya leveraging terhadap salah satu assets pipeline yakni pada kasus ini Session Data untuk RCE

\subsection{Serangan pada Ruby on Rails Melalui Konversi Otomatis pada Tipe Data}

Serangan pada aplikasi Rails dapat dilakukan dengan menyalahgunakan fitur konversi otomatis pada tipe data pada MySQL (untuk kasus dimana Rails diimplementasikan dengan basis data MySQL). Serangan ini reset password pada aplikasi Ruby on Rails [6]. Teknik yang biasa digunakan untuk melakukan reset password pada aplikasi berbasis web adalah mengirimkan sebuah token ke pengguna melalui email atau fitur email pada aplikasi, yang memungkinkan pengguna untuk melakukan reset password. Hal ini juga dapat diberlakukan pada aplikasi Rails yang menyalahgunakan fitur konversi otomatis pada MySQL. Pada aplikasi Rails, bentuk token guna reset password adalah sebagai berikut:

\# PasswordController

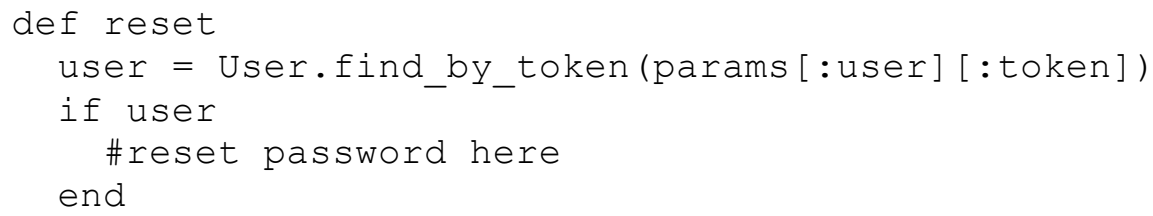

Params pada token tersebut menghasilkan sebuah string acak, misal "TokenAcak". Berbekal pengetahuan tentang MySQL typecasting dan fakta-fakta tentang masukkan JSON/XML, maka dapat dibangun pola serangan pada aplikasi Rails tersebut. MySQL akan mencocokkan string "TokenAcak" dengan angka 0, sehingga exploit yang mungkin pada aplikasi Rails tersebut dapat berbentuk:

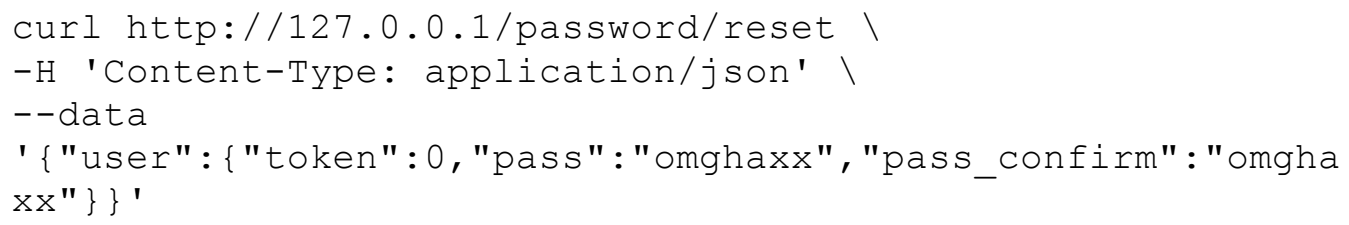


Exploit dilakukan melalui shell scipt dari komputer penyerang. Hasil dari exploit tersebut adalah penyerang dapat login ke aplikasi Rails menggunakan sembarang password walau harus menebak username terlebih dahulu. Namun banyak sistem yang dikembangkan dengan memiliki pengguna dengan username administrator, root, atau semacamnya.

\subsection{Injeksi Kode pada Aplikasi Berbasis Ruby on Rails}

Injeksi kode dapat dilakukan terhadap aplikasi Rails dengan memanfaatkan mekanisme eksekusi kode melalui unmarshalling session cookie. Terdapat cara pencurian data dengan menggunakan session cookie, walau dalam hal ini hanya dapat diterapkan pada data berukuran kecil (kurang dari 4kB). Teknik pencurian data ini menggunakan muatan spesifik pada kode yang diinjeksikan, yang berbentuk:

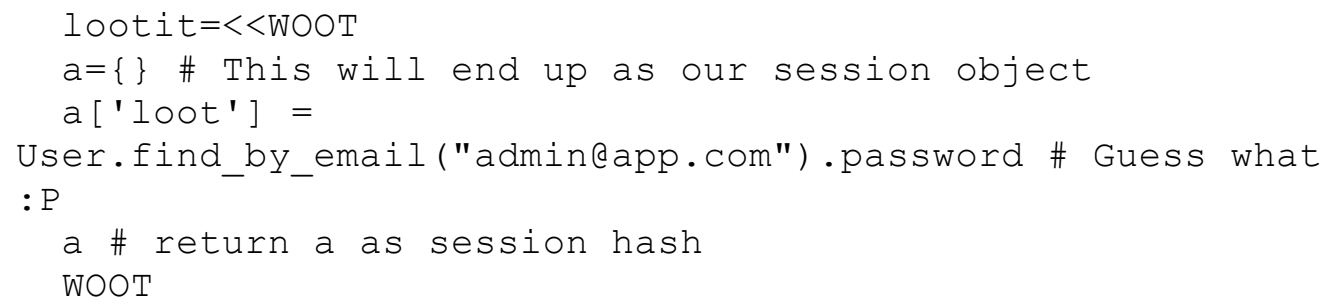

yang mana selanjutnya digunakan_string_ pada cookie menggunakan teknik Remote Code Execution (RCE). Jika dilakukan dengan benar, respon terhadap cookie akan memuat cookie baru yang mengandung sebuah kunci 'loot' yang memiliki nilai yakni data yang diminta.

Mekanisme serangan lain yang dapat dilakukan adalah injeksi kode yang menulis ulang login controller dari aplikasi sedemikian rupa sehingga akan logging out semua pengguna serta baru kemudian menyimpan semua password yang masuk pada memori sampai passwordpassword tersebut fetched oleh permintaan spesifik. Muatan injeksi kode pada mekanisme ini adalah sebagai berikut:

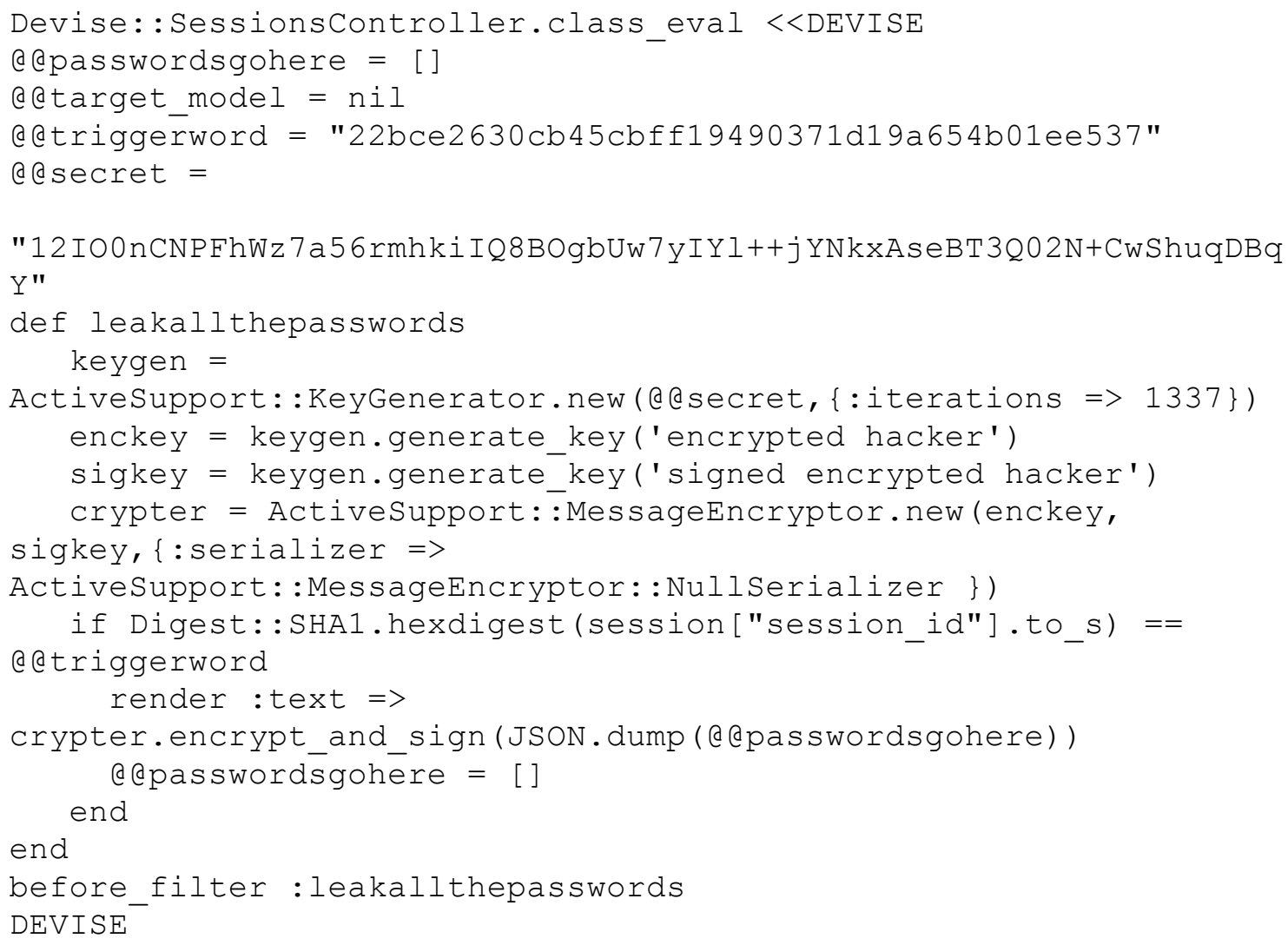


Jika dilakukan RCE pada aplikasi Rails dengan kode tersebut akan memunculkan filter pada login Controller dari aplikasi Rails yang dilakukan RCE terhadapnya. Filter tersebut yakni leakallthepasswords yang membuang semua password tersebut pada id sesi spesifik serta menghapusnya dari memori. Dengan memanfaatkan eval() atau muatan RCE berbasis session cookie, penyerang dapat dengan bebas membangun mekanisme pengendalian pada aplikasi Rails target, dimana muatan akan tinggal pada memori hingga aplikasi target dimatikan. Dengan demikian mekanisme serangan seperti ini relatif susah ditelusuri secara cyber forensic.

\subsection{Contoh Pencegahan Serangan}

Terkait dengan pola serangan yang telah dirumuskan, terdapat beberapa contoh cara pencegahan yakni:

- enforcing SSL dengan fungsi config.ssl = true guna mencegah sniffing terhadap session id

- menghindari session fixation dengan fungsi reset_session yang meregenerasi session setiap setelah otentikasi

- menyimpan session pada database (session by default tersimpan di cookie), dengan fungsi PCCMain: Application.config.session_store :active_record_store

- Proteksi CSRF dengan CSRF token generation and checking enforced by default. Cara ini dilakukan dengan kode:

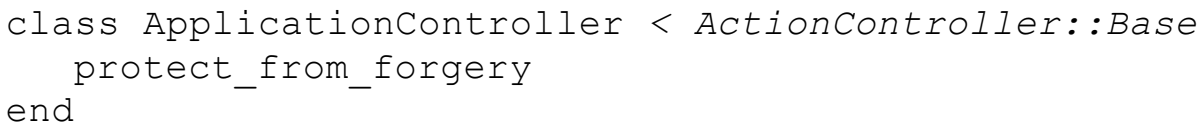

\section{KESIMPULAN}

Secara umum Rails merupakan platform pengembangan aplikasi berbasis web yang relatif tidak mudah untuk diserang. Namun tetap saja ada pola-pola yang selalu dapat ditelusuri guna menentukan mekanisme serangan. Mekanisme-mekanisme serangan pada Rails dilakukan dengan memanfaatkan fitur input via JSON/XML atau yang lebih berbahaya yakni dengan code injection. Kedua mekanisme serangan tersebut dimungkinkan untuk dilakukan dengan memanfaatkan kelengahan pengembang aplikasi dengan tidak menerapkan secure programming.

\section{DAFTAR PUSTAKA}

[1] Romaric Ludinard, Eric Totel, Frederic Tonel, Mohamed Kaaniche, Eric Alata, Rim Akrout, and Yann Bachy, "An Invariant-Based Approach for Detecting Attacks Against Data in Web Applications", International Journal of Secure Software Engineering, 5(1), January-March, 19-38, 2014.

[2] Kelly Smith, "37 Sites You LOVE Built with Ruby On Rails", skillcrush.com, April 28, 2017. [Online]. Available: https://skillcrush.com/2015/02/02/37-rails-sites/. [Accessed May $15,2017]$.

[3] David. "Rails 1.0: Party like it's one oh oh!". Ruby on Rails. Retrieved 2017-03-01.

[4] Felix Lindner, "A rather informal advisory on Fat Free CRM", phenoelit: http://www.phenoelit.org/stuff/ffcrm.txt, August 27, 2016. [Accessed May 19, 2017].

[5] rapid7, "metasploit-framework", GitHub: https://github.com/rapid7/metasploitframework/blob/master/modules/exploits/multi/http/spree searchlogic exec.rb, July 24, 2017. [Accessed July 27, 2017].

[6] Felix Lindner, "Ruby on Rails - Auditing \& Exploiting the Popular Web Framework", black hat: https://www.blackhat.com/latestintel/04302014-poc-in-the-cfp.html, August 2014. [Accessed July 29, 2017]. 